\title{
Vaccination with Astragalus and Ginseng Polysaccharides Improves Immune Response of Chickens against H5N1 Avian Influenza Virus
}

\author{
Auwalu Yusuf Abdullahi, ${ }^{1,2}$ Sanpha Kallon, ${ }^{3,4}$ Xingang Yu, ${ }^{1}$ \\ Yongliang Zhang, ${ }^{3}$ and Guoqing $\mathrm{Li}^{1}$ \\ ${ }^{1}$ Guangdong Provincial Zoonosis Prevention and Control Key Laboratory, College of Veterinary Medicine, \\ South China Agricultural University, Guangzhou 510542, China \\ ${ }^{2}$ Animal Science Department, Kano University of Science and Technology Wudil, PMB 3244, Kano 20027, Nigeria \\ ${ }^{3}$ Animal Science Department, Njala University, Freetown, Sierra Leone \\ ${ }^{4}$ College of Animal Science, South China Agricultural University, Guangzhou 510542, China
}

Correspondence should be addressed to Yongliang Zhang; zhangyl@scau.edu.cn and Guoqing Li; gqli@scau.edu.cn

Received 11 May 2016; Revised 7 July 2016; Accepted 14 July 2016

Academic Editor: Abdelwahab Omri

Copyright (C) 2016 Auwalu Yusuf Abdullahi et al. This is an open access article distributed under the Creative Commons Attribution License, which permits unrestricted use, distribution, and reproduction in any medium, provided the original work is properly cited.

To determine the effect of astragalus and ginseng polysaccharides (APS, GPS) on immune response and improvement of H5N1 vaccine, 360-day-old broilers were randomly divided into 8 groups of 45 chicks, comprising APS groups (1-3); GPS groups (4-6); vaccine group (7); and blank control (8) (without polysaccharide and vaccine). From day 12 after hatch groups 1-3 were given APS and groups 4-6 with GPS both at 100, 200, and $400(\mathrm{mg} / \mathrm{kg})$, respectively. At day 15 after hatch, groups 1-7 were vaccinated with $0.3 \mathrm{~mL}$ H5N1 vaccine subcutaneously; daily weight gain (DWG) and serum Ig antibody (by HI-test) were measured on 3, 7, 14, and 28 days after vaccination. Serum antibody titers and expression of cytokines (IL-2, IL-10, I FN- $\gamma$, and TNF) were determined by ELISA and RT-PCR. Results revealed that all the polysaccharide groups were numerically increased in antibody levels and the expression of cytokines was significant $(P<0.05)$ in the APS and GPS groups compared to corresponding vaccine group and blank control. DWG was higher $(P<0.05)$ in $400 \mathrm{mg} / \mathrm{kg}$ APS groups than control groups. Thus oral supplements of GPS and APS have shown their potential in the improvement of immune response and could be used as adjuvant in a formulation of H5N1 vaccine.

\section{Introduction}

H5N1 is an avian (bird) flu virus that has caused outbreaks in domestic poultry in parts of Asia and the Middle East. As $\mathrm{H} 5 \mathrm{~N} 1$ is so deadly to poultry, it is considered "highly pathogenic.” Since 2006, nearly 600 human infections with highly pathogenic $\mathrm{H} 5 \mathrm{~N} 1$ viruses have been reported to the World Health Organization (WHO) from 15 countries in Asia, Europe, and the Middle Near East. About $60 \%$ of these people died from this illness [1]. The first avian influenza virus to infect humans occurred in Hong Kong in 1997. The epidemic was linked to chickens and classified as avian influenza A (H5N1). Infected birds can shed influenza virus in their saliva, nasal secretions, and feces. Susceptible birds become infected when they have contact with contaminated secretions or excretions or with surfaces that are contaminated with secretions or excretion from infected birds [2].

The availability and use of effective vaccines can be a valuable tool in controlling outbreaks of avian influenza. Adjuvant killed vaccines can provide a strong humoral response and have been proved to be effective in preventing disease from mildly pathogenic avian influenza (MPAI) and highly pathogenic avian influenza (HPAI) challenges [3]. The HPAI virus is highly lethal in poultry and can cause large outbreaks leading to substantial economic loss and can spread directly from poultry to human, constituting a possible "pandemic threat" to the human population [4]

Astragalus polysaccharide (APS) possesses main components such as mannose, D-glucose, D-galactose, xylose, and 
L-arabinose. This polysaccharide is used as an immunomodulating agent in mixed herbal decoctions to treat common cold, diarrhea, fatigue, and anorexia [5]. It can also stimulate cell proliferation, induce the expression of surface antigens on lymphocytes, and affect the expression of cytokines and promote the production of antibodies [6]. Panax ginseng polysaccharide (GPS), on the other hand, contains several components such as ginsenosides, essential oil, peptidoglycans, polysaccharides, nitrogen-containing compounds, fatty acid, and phenolic compounds $[7,8]$. It is well-known traditional Chinese herbal medicine. Logical studies have shown that GPS had multifunctions such as promoting the production of cytotoxic cells against tumors and stimulated macrophages to produce helper types 1 and 2 (Th1 and Th2) cytokines $[9,10]$. GPS was also shown to modulate the antioxidant defense system such as superoxide dismutase and glutathione peroxidase probably via inducing regulatory cytokines $[11,12]$. As anti-inflammatory responses at an early phase it results in the enhancement of antimicrobial activities and protection of mice from staphylococcus aureus-induced sepsis $[13,14]$. Our previous work with APS and GPS on H9N2 indicated that APS treatment reduced H9N2 AIV replication; GPS was enhanced by pretreatment of CEF, and both have promoted early humoral immune responses in young chickens $[15,16]$.

In this research, we tested vaccinated and nonvaccinated chickens with $\mathrm{H} 5 \mathrm{~N} 1$ vaccine to evaluate the immunoregulatory effect of APS and GPS on chickens and assess the immunization potential of APS and GPS against H5N1 avian influenza.

\section{Materials and Methods}

2.1. Ethics. All animal experiments and husbandry involved in this study were treated in accordance with the guidelines of the South China Agricultural University Animal Care and Use Committee, which operates under the Animal Welfare Law and Regulations of the Department of Health and Human Services. The South China Agricultural University Animal Care and Use Committee has approved all protocols of this study.

\subsection{APS and GPS. APS was bought from MEDICASS Com-} pany in Beijing China and GPS was provided by the Animal Science College of South China Agricultural University. GPS was extracted and purified as described in our previous works $[15,16]$. Trizol, isopropanol, chloroform [trichloromethane], DEPC water, and 75\% ethanol were used in the extraction of RNA. DNase1 [ $5 \mathrm{u} / \mu \mathrm{L}$ ], DNasel buffer [10x], RNase inhibitor, agarose powder, and ethidium bromide were the other reagents used.

2.3. Purification of the Polysaccharides. The polysaccharides were purified as follows: removal of protein and pigment by salvage method [17] and active carbon adsorption and then through D101 macroaperture resin column, ADS-7 polymer adsorbents column, A-25 DEAE cellulose, and G-75 Sephadex column [18]. The polysaccharide contents (\%) of
APS and GPS were measured by vitriol-anthrone [17] taking anhydrous glucose as standard control. The percentage content (\%) of APS and GPS were 79.50 and 75, respectively. For details refer to our previous works $[15,16]$.

2.4. Vaccine. The inactive avian influenza vaccine ( $\mathrm{H} 5 \mathrm{~N} 1 \mathrm{sub}-$ type) was obtained from South China Agricultural University Poultry Farm and $0.3 \mathrm{~mL}$ was injected subcutaneously on the dorsal region of the neck of 15-day-old chickens.

2.5. Experimental Design. Three hundred and sixty, 1-day-old Yue Huang avian broilers with an average weight of $60.5 \mathrm{~g}$ were randomly divided into 8 groups of 45 chicks each. They were housed in wire cages in air-conditioned room at $37^{\circ} \mathrm{C}$ and lighted for $24 \mathrm{~h}$ at the beginning of pretrial period. The temperature was gradually decreased to room temperature; lighting period was 12 hours per day. Chickens were fed with commercial starter diet, purchased from the university poultry farm. From day 12 after hatch groups 1-3 were supplemented orally with APS at $100 \mathrm{mg} / \mathrm{kg}$, $200 \mathrm{mg} / \mathrm{kg}$, and $400 \mathrm{mg} / \mathrm{kg}$ and groups $4-6$ with GPS at $100 \mathrm{mg} / \mathrm{kg}, 200 \mathrm{mg} / \mathrm{kg}$, and $400 \mathrm{mg} / \mathrm{kg}$, respectively. Each dose of polysaccharide was dissolved in $1000 \mathrm{~mL}$ of water (till the end of the experiment). At 15 days after hatch, groups 1-7 were vaccinated with $0.3 \mathrm{~mL}$ H5N1 vaccine subcutaneously on the dorsal region of the neck, where group 7 only received vaccine without polysaccharide and group 8 was blank control without polysaccharide and vaccine. At 3, 7, 14, and 28 days after vaccination ten birds from each group (groups 1-8) were weighed before being euthanized by cervical dislocation; then blood samples were collected to separate serum and stored at $-20^{\circ} \mathrm{C}$ until use. At the same time the spleen was weighed and immediately stored in liquid nitrogen. ELISA and RT-PCR tests were performed to determine the percentage of serum antibody titers and expression of cytokines (IL-2, IL-10, I FN- $\gamma$, and TNF).

2.6. Determination of Growth Performance. Weight of each bird was measured on days 3, 7, 14, and 28 after vaccination and effect on weight gain was recorded. Average live body weight, total weight gain, and daily weight gain of different groups were compared.

2.7. Measurement of Antibody Titer. Antibody titer was measured by hemagglutination inhibition (HI) test [19]. The $\mathrm{HI}$ test was a standard beta test, using 4 hemagglutinating units of antigen in 96-well plates, where the test serum had been diluted twofold. HI endpoint titers were determined as the reciprocal of the highest serum dilution that produced complete inhibition of hemagglutination.

2.8. RNA Extraction. Samples of spleen from the various groups of chickens were frozen in liquid nitrogen. About $60 \mathrm{~g}$ to $80 \mathrm{~g}$ of the tissue were cut into smaller pieces with sterilized scissors and washed with PBS. One mL of Trizol (RNA-solv Reagent) was added and the pieces were grinded by a polytron grinder to homogenize the tissue. The solution was placed in dry ice for 2-3 min to prevent the degradation of the RNA. 
TABLE 1: Sequence of the oligonucleotide primers used in Real-Time PCR.

\begin{tabular}{|c|c|c|c|}
\hline Gene name & Primer $\left(5^{\prime} \rightarrow 3^{\prime}\right)$ & Product (bp) & Accession number \\
\hline \multirow{2}{*}{ IL-2 } & F: CTTTGGCTGTATTTCGG & \multirow{2}{*}{163} & \multirow{2}{*}{ NM-204153.1 } \\
\hline & R: CTGGGTCTCAGTTGGTGT & & \\
\hline \multirow{2}{*}{ IL-10 } & F: GCTGAGGGTGAAGTTTGAG & \multirow{2}{*}{192} & \multirow{2}{*}{ NM-001004414.2 } \\
\hline & R: TGATGACTGGTGCTGGTCT & & \\
\hline \multirow{2}{*}{ TNF- $\alpha$} & F: CTCAGGACAGCCTATGCCA & \multirow{2}{*}{171} & \multirow{2}{*}{ AY765397.1 } \\
\hline & R: CACGACAGCCAAGTCAACG & & \\
\hline \multirow{2}{*}{ IFN- $\beta$} & F: CATACTGAGCCAGATTGTTTCG & \multirow{2}{*}{176} & \multirow{2}{*}{ NM-205149.1 } \\
\hline & R: TCAAGTCGTTCATCGGGAG & & \\
\hline \multirow{2}{*}{$\beta$-actin } & F: TGATATTGCTGCGCTCGTTG & \multirow{2}{*}{202} & \multirow{2}{*}{ JF436880.1 } \\
\hline & R: CTTTCTGGCCCATACCAACC & & \\
\hline
\end{tabular}

The mixture was harvested at $12000 \mathrm{rpm}$ for $10 \mathrm{~min}$ at $4^{\circ} \mathrm{C}$. This was done to precipitate the undegraded substances such as DNA, proteins, and lipids. A short break was taken at this point; thereafter the content was poured into a new tube and $200 \mu \mathrm{L}$ of trichloromethane (chloroform) was added in order to separate RNA from DNA and protein. The content was shaken for $15 \mathrm{~s}$ and harvested at $12000 \mathrm{rpm}$ for $15 \mathrm{~min}$ at $4^{\circ} \mathrm{C}$. The aqueous upper phase (colorless liquid) was transferred in a new tube and $500 \mu \mathrm{L}$ of isopropanol was added and shaken for few seconds. The isopropanol was used to precipitate the RNA and the content was incubated at $-20^{\circ} \mathrm{C}$ for $30 \mathrm{~min}$ and centrifuged at $12000 \mathrm{rpm}$ for $10 \mathrm{~min}$. RNA was precipitated and the supernatant was discarded leaving RNA pellet at the bottom of the tube. The tube was knocked slightly to displace the RNA and then washed with $1 \mathrm{~mL}$ of $75 \%$ ethanol. The content was harvested at $7500 \mathrm{rpm}$ for $5 \mathrm{~min}$ at $4^{\circ} \mathrm{C}$ and the supernatant was discarded and the tube was placed upside down to dry the RNA for 5-10 min. After drying, the RNA pellet was dissolved in $50 \mu \mathrm{L}$ DEPC-treated $\mathrm{H}_{2} \mathrm{O}$, vortexed and briefly centrifuged for $10 \mathrm{~s}$.

2.9. Real-Time PCR. The total RNA was extracted from tissues using Trizol reagent (Takara Biotechnology, Dalian, China) for the detection of cytokines and H5N1 expression was tested by ultraviolet spectrophotometer at an optical density range of 1.8-2.0. The isolated RNA was digested with DNasel (Takara Biotechnology, Dalian, China) at $37^{\circ} \mathrm{C}$ for $30 \mathrm{~min}$. One (1) $\mu \mathrm{g}$ of total RNA was used for reverse transcript with Rever Tra Ace QPCR RT kit (Toyobo Osaka, Japan) and amplifications were performed with $1 \mu \mathrm{L}$ cDNA in a total volume of $20 \mu \mathrm{L}$. SYBR Green Real-Time PCR Master Mix (Roch Mortlake, Australia) was conducted with the Strata gene Mx3005P QPCR system (Strata gene) according to the manufacturer's instruction. All reactions were done in triplicate. Relative expression fold change was calculated by $2^{-\Delta \Delta \mathrm{Ct}}$ method and $\beta$-actin was used as the endogenous reference gene to normalize the expression level of target gene. The primers used in the RT-PCR were listed in Table 1.

2.10. Detection of Interleukins (IL-2 and IL-10) in Chicken's Serum by ELISA. The ELISA Kits were purchased from
Kemeidongya Biotechnology Company, Beijing, China, and were used to assay the levels of chicken interleukin 2 and interleukin 10 according to the manufacturer's instructions. The standard solutions were prepared from an original standard $(640 \mathrm{ng} / \mathrm{L})$ by serial dilution. Then the standard solutions ( $50 \mu \mathrm{L} /$ well) were pipetted into the wells of the first row of the microelisa striplate leaving the first two wells blank and serum sample ( $40 \mu \mathrm{L} /$ well) was pipetted into the remaining wells (two wells/group sample). Biotin-interleukin antibody $(10 \mu \mathrm{L})$ was added followed by Str-HRP-Conjugate Reagent $(50 \mu \mathrm{L} /$ well). The microelisa striplate was sealed with closure plate membrane, shaken slightly, and incubated for $1 \mathrm{~h}$ at $37^{\circ} \mathrm{C}$. Thereafter, the closure membrane was removed and liquid was drained and microelisa plate was washed five times by filling each well with wash buffer $(350 \mu \mathrm{L})$ using a squirt bottle, multichannel pipette, manifold dispenser, or auto washer. After the last wash, the remaining wash buffer was removed by aspirating or decanting and the plate was invert and blotted against clean paper towels. Chromogen solution A ( $50 \mu \mathrm{L} /$ well) was pipetted to each well followed by Chromogen B $(50 \mu \mathrm{L})$ which was protected from light to avoid light sensitive and thereafter it was incubated for $10 \mathrm{~min}$ at $37^{\circ} \mathrm{C}$. Stop solution $(50 \mu \mathrm{L})$ was quickly added into each well to stop the reaction which was indicated by an instant change of blue to yellow color.

Taking the blank well as zero, measurement of the optical density (OD) under $450 \mathrm{~nm}$ wavelength was carried out within $10 \mathrm{~min}$ after adding the stop solution. According to the standard concentration and the corresponding OD values, the standard curve linear regression equation was calculated and then the OD values of the sample were applied on the regression equation to calculate the corresponding sample's concentration.

2.11. Statistical Analysis. All data were shown as mean \pm SEM. Comparisons between two groups were analyzed using unpaired Student's $t$-tests and among multiple groups by ANOVA followed by a post hoc analysis using the Turkey's multiple comparison test using SPSS 17.0 software (SPSS, Chicago, IL, USA). A probability values $(P<0.05)$ was considered to be statistically significant. All experiments were performed at least three times. 
TABLE 2: Effect of APS and GPS on body weight gain (g).

\begin{tabular}{|c|c|c|c|c|}
\hline Groups & D3 & D7 & D14 & D28 \\
\hline APS (100 mg/kg) & $117.8 \pm 8.49$ & $148.3 \pm 11.59^{\mathrm{b}}$ & $214.9 \pm 12.44^{\mathrm{c}}$ & $396.1 \pm 21.31^{\mathrm{b}}$ \\
\hline GPS (100 mg/kg) & $107.2 \pm 9.51$ & $146.9 \pm 13.03^{b}$ & $207.1 \pm 20.6^{c}$ & $398.4 \pm 23.82^{\mathrm{b}}$ \\
\hline APS (200 mg/kg) & $113.3 \pm 10.99$ & $150.6 \pm 12.5^{\mathrm{b}}$ & $240.5 \pm 16.43^{\mathrm{b}}$ & $397.8 \pm 22.53^{\mathrm{b}}$ \\
\hline GPS (200 mg/kg) & $112.6 \pm 8.9$ & $145.7 \pm 12.96^{\mathrm{b}}$ & $213.4 \pm 25.42^{c}$ & $371.5 \pm 28.5^{\mathrm{b}}$ \\
\hline APS $(400 \mathrm{mg} / \mathrm{kg})$ & $119.2 \pm 10.78$ & $166.4 \pm 13.01^{\mathrm{a}}$ & $261.4 \pm 18.7^{\mathrm{a}}$ & $432.0 \pm 23.65^{\mathrm{a}}$ \\
\hline GPS (400 mg/kg) & $117.6 \pm 8.48$ & $147.3 \pm 14.15^{\mathrm{b}}$ & $235.8 \pm 22.73^{\mathrm{b}}$ & $410.51 \pm 27.34^{b}$ \\
\hline Vaccine & $109.7 \pm 9.72$ & $139.7 \pm 14.73^{c}$ & $197.5 \pm 21.91^{c}$ & $382.2 \pm 23.9^{\mathrm{b}}$ \\
\hline Blank control & $117.2 \pm 9.07$ & $146.8 \pm 13.03^{\mathrm{b}}$ & $235.8 \pm 22.73^{b}$ & $382.8 \pm 24.79^{b}$ \\
\hline
\end{tabular}

Superscripts with different letters $(a, b$, and $c)$ differ significantly $(P<0.05)$. APS = astragalus polysaccharide; GPS = ginseng polysaccharide; $\mathrm{D}=$ day.

\section{Results}

3.1. Differences in Body Weight. Differences in weight gain during experimental period were shown in Table 2. The weight differences of the various groups were recorded on days $3,7,14$, and 28 . There was an increase in weight gain on days 7,14 , and 28 by all the groups and the weight gains of the experimental groups were significant $(P<0.05)$. On days 7 and 14 the APS groups of $200 \mathrm{mg} / \mathrm{kg}$ and $400 \mathrm{mg} / \mathrm{kg}$ were higher than the corresponding groups, while on day 28 the body weight of APS $(400 \mathrm{mg} / \mathrm{kg})$ group was higher than corresponding GPS groups including vaccine and blank control. On day 3 there was no significant difference in body weight gain between the APS and GPS groups $(P>0.05)$. Hence, APS group of $400 \mathrm{mg} / \mathrm{kg}$ was higher $(P<0.05)$ than all at 7,14 , and 28 days.

3.2. Changes in Serum Antibody Titer. Changes in serum antibody titers were shown in Figures 1 and 2. On day 3 after immunization, the antibody titer of all levels of APS treated groups was not different $(P>0.05)$ from vaccine group and blank control. But on days 7, 14, and 28 after vaccination APS were significantly different $(P<0.05)$ from corresponding nonpolysaccharide treated groups. On day 28 the antibody titer level of $400 \mathrm{mg} / \mathrm{kg}$ APS treated group was higher $(P<$ $0.01)$ than vaccine group and blank control. However, it was observed that on days 14 and 28 the antibody titer level of blank control was significantly lower $(P<0.01)$ than vaccine group (Figure 1).

For GPS on day 3, after immunization the antibody titer level of $100 \mathrm{mg} / \mathrm{kg}$ GPS treated group was higher $(P<0.05)$ than vaccine group and blank control. Similarly on day 7 , the antibody titer levels of the $200 \mathrm{mg} / \mathrm{kg}$ GPS treated group was higher $(P<0.05)$ than vaccine group and blank control. On day 28 the antibody titer level of $200 \mathrm{mg} / \mathrm{kg}$ GPS treated group was significantly higher $(P<0.01)$ than vaccine and blank control, while the antibody titer levels of the $100 \mathrm{mg} / \mathrm{kg}$ and $400 \mathrm{mg} / \mathrm{kg}$ GPS treated groups were higher $(P<0.05)$ than vaccine group and blank control. However, on days 14 and 28 the antibody titer level of the blank control was significantly very low $(P>0.01)$, while on day 7 it was significantly lower $(P>0.05)$ than vaccine group (Figure 2$)$.

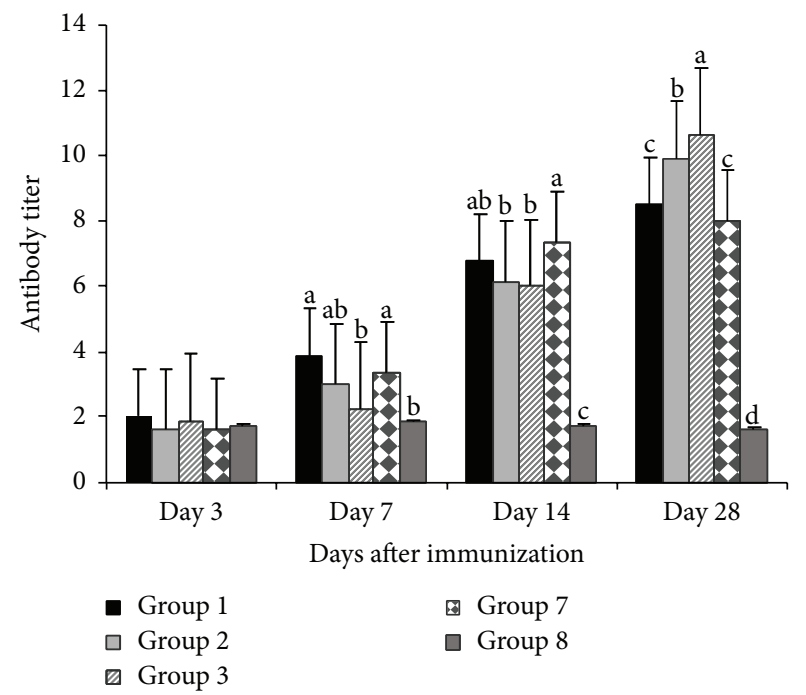

FIGURE 1: Antibody titers of APS treated groups and control groups. Superscripts with different letters (a-d) differ significantly $(P<$ 0.05). Group $1=100 \mathrm{mg} / \mathrm{kg}$ APS + vaccine. Group $2=200 \mathrm{mg} / \mathrm{kg}$ APS + vaccine. Group $3=400 \mathrm{mg} / \mathrm{kg}$ APS + vaccine. Group 7 = vaccine only. Group 8 = no vaccine, no APS (blank control).

3.3. Expression of Cytokines. Figure 3 revealed that on day 3 after vaccination the TNF- $\alpha$ gene expressions of the polysaccharide treated groups (all levels of APS and $100 \mathrm{mg} / \mathrm{kg}$ and $400 \mathrm{mg} / \mathrm{kg}$ GPS $)$ were higher $(P<0.05)$ than corresponding nonpolysaccharide treated groups, while, on day 7 , the gene expressions of polysaccharide treated groups $(200 \mathrm{mg} / \mathrm{kg}$ and $400 \mathrm{mg} / \mathrm{kg}$ of both APS and GPS) were higher $(P<0.01)$ than nonpolysaccharide treated groups. Similarly on days 14 and 28 , the gene expressions of the polysaccharide treated groups (200 mg/kg and $400 \mathrm{mg} / \mathrm{kg}$ APS and $400 \mathrm{mg} / \mathrm{kg}$ GPS) were higher $(P<0.01)$ than corresponding nonpolysaccharide treated groups.

Figure 4 depicted that on day 3 the IFN- $\beta$ gene expressions of the experimental groups $(200 \mathrm{mg} / \mathrm{kg}$ and $400 \mathrm{mg} / \mathrm{kg}$ APS; and all levels of GPS) were higher $(P<0.01)$ than vaccine group and blank control. Equally, on day 7 the gene expression of the $400 \mathrm{mg} / \mathrm{kg}$ APS treated group was higher $(P<0.01)$, while both APS and GPS group at 


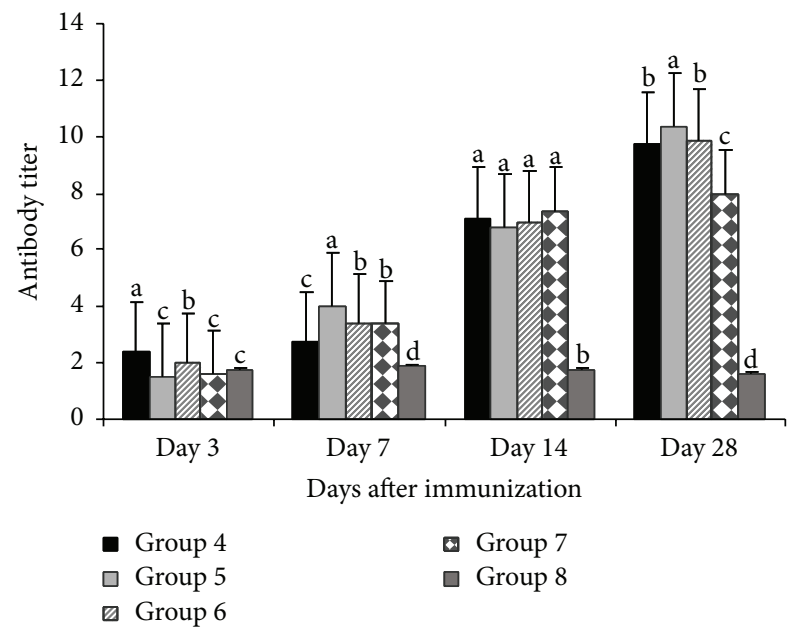

FIGURE 2: Antibody titers of GPS treated groups and control groups. Superscripts with different letters $(\mathrm{a}-\mathrm{d})$ differ significantly $(P<$ $0.05)$. Group $4=100 \mathrm{mg} / \mathrm{kg}$ GPS + vaccine. Group $5=200 \mathrm{mg} / \mathrm{kg}$ GPS + vaccine. Group $6=400 \mathrm{mg} / \mathrm{kg}$ GPS + vaccine. Group $7=$ vaccine only. Group $8=$ no vaccine, no GPS (blank control).

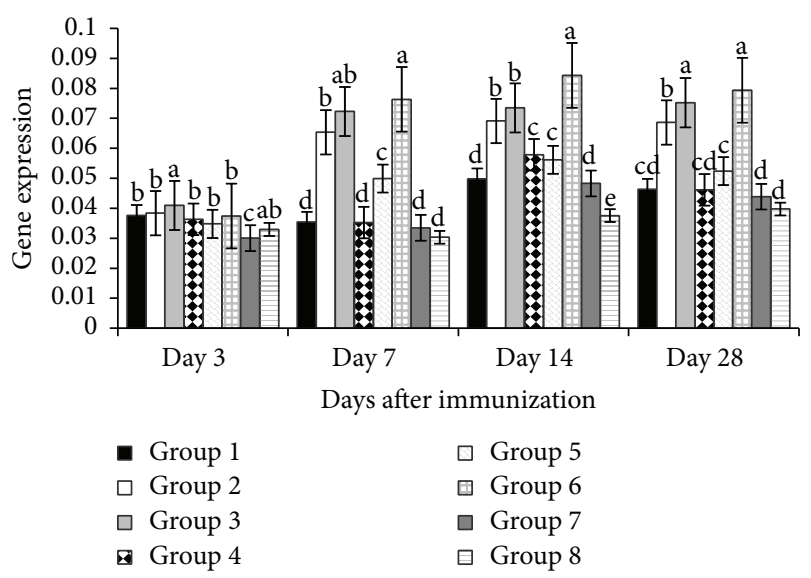

Figure 3: Effect of APS and GPS on gene expression of TNF- $\alpha$. Superscripts with different letters (a-e) differ significantly $(P<$ 0.05). Group $1=100 \mathrm{mg} / \mathrm{kg}$ APS + vaccine. Group $2=200 \mathrm{mg} / \mathrm{kg}$ APS + vaccine. Group $3=400 \mathrm{mg} / \mathrm{kg}$ APS + vaccine. Group $4=100 \mathrm{mg} / \mathrm{kg}$ GPS + vaccine. Group $5=200 \mathrm{mg} / \mathrm{kg}$ GPS + vaccine. Group $6=$ $400 \mathrm{mg} / \mathrm{kg}$ GPS + vaccine. Group $7=$ vaccine only. Group $8=$ no vaccine, no GPS (blank control).

$200 \mathrm{mg} / \mathrm{kg}$ were significant $(P<0.05)$ compared with vaccine group and blank control. Furthermore on days 14 and 28 after vaccination, the gene expressions of the polysaccharide treated groups, all levels of both APS and GPS were higher $(P<0.01)$ than nonpolysaccharide treated groups.

Figure 5 illustrated that, on day 3 , the IL-2 gene expression of the $200 \mathrm{mg} / \mathrm{kg}$ and $400 \mathrm{mg} / \mathrm{kg}$ GPS treated groups were higher $(P<0.01)$, while the $200 \mathrm{mg} / \mathrm{kg}$ and $400 \mathrm{mg} / \mathrm{kg}$ APS and the $100 \mathrm{mg} / \mathrm{kg}$ GPS treated groups were higher $(P<0.05)$ than vaccine group and blank control. We observed that on days 3, 7, and 28 the gene expressions of all levels of GPS

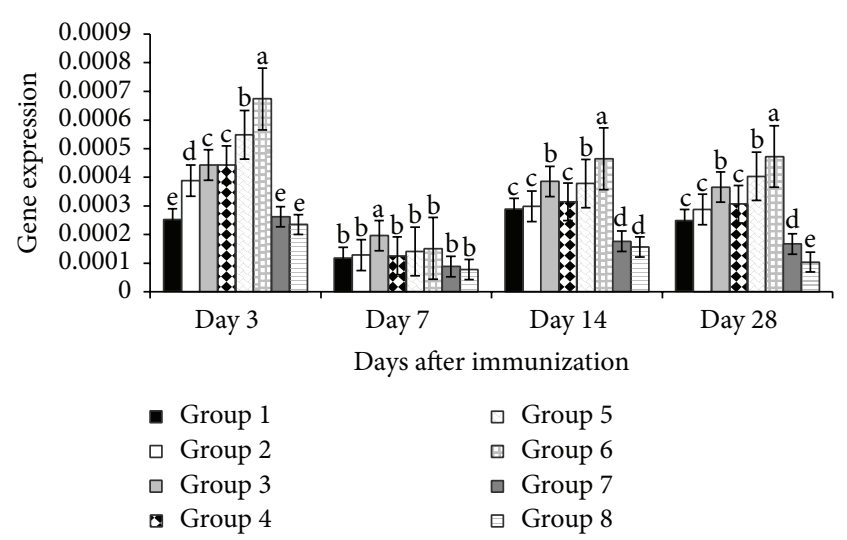

FIGURE 4: Effect of APS and GPS on gene expression of IFN- $\beta$. Superscripts with different letters $(\mathrm{a}-\mathrm{e})$ differ significantly $(P<$ $0.05)$. Group $1=100 \mathrm{mg} / \mathrm{kg}$ APS + vaccine. Group $2=200 \mathrm{mg} / \mathrm{kg}$ APS + vaccine. Group $3=400 \mathrm{mg} / \mathrm{kg}$ APS + vaccine. Group $4=100 \mathrm{mg} / \mathrm{kg}$ GPS + vaccine. Group $5=200 \mathrm{mg} / \mathrm{kg}$ GPS + vaccine. Group $6=$ $400 \mathrm{mg} / \mathrm{kg}$ GPS + vaccine. Group $7=$ vaccine only. Group $8=$ no vaccine, no GPS (blank control).

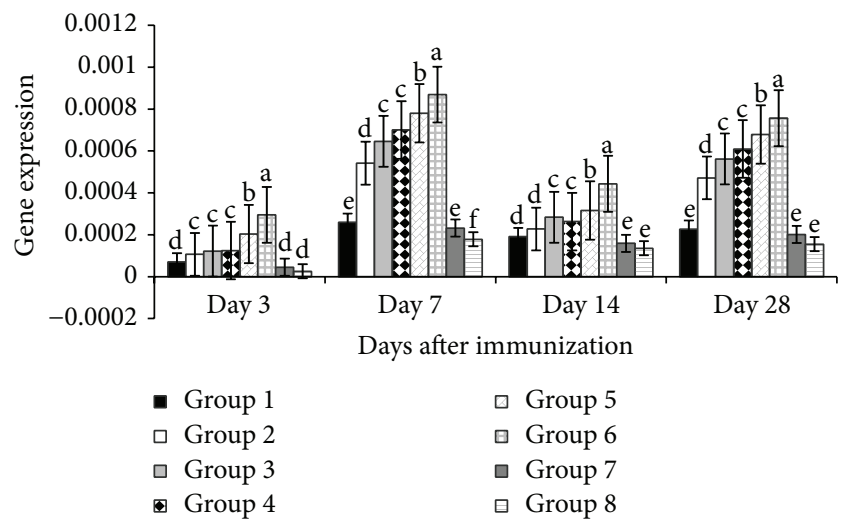

FIGURE 5: Effect of APS and GPS on IL-2 gene expression. Superscripts with different letters $(a-f)$ differ significantly $(P<0.05)$. Group $1=100 \mathrm{mg} / \mathrm{kg}$ APS + vaccine. Group $2=200 \mathrm{mg} / \mathrm{kg}$ APS + vaccine. Group $3=400 \mathrm{mg} / \mathrm{kg}$ APS + vaccine. Group $4=100 \mathrm{mg} / \mathrm{kg}$ GPS + vaccine. Group $5=200 \mathrm{mg} / \mathrm{kg}$ GPS + vaccine. Group $6=$ $400 \mathrm{mg} / \mathrm{kg}$ GPS + vaccine. Group $7=$ vaccine only. Group $8=$ no vaccine, no GPS (blank control).

treated groups were higher $(P<0.05)$ than the corresponding APS groups. And on days 7, 14, and 28 IL-2 gene expressions of the $400 \mathrm{mg} / \mathrm{kg}$ APS and GPS treated groups were higher $(P<$ 0.01 ); likewise on days 7 and 28 , the IL-2 gene expressions of APS and GPS treated groups have shown similar trend.

Figure 6 showed that, on days 3, 7, 14, and 28 after immunization, the IL-10 gene expressions of both $200 \mathrm{mg} / \mathrm{kg}$ and $400 \mathrm{mg} / \mathrm{kg}$ of APS and GPS treated groups were higher $(P<0.01)$ than vaccine group and blank control, while the IL-10 gene expressions of the $100 \mathrm{mg} / \mathrm{kg}$ APS and GPS were higher $(P<0.05)$ than vaccine group and blank control. On days $3,7,14$, and 28 the IL-10 gene expressions of the $200 \mathrm{mg} / \mathrm{kg}$ and $400 \mathrm{mg} / \mathrm{kg}$ GPS treated groups were higher 


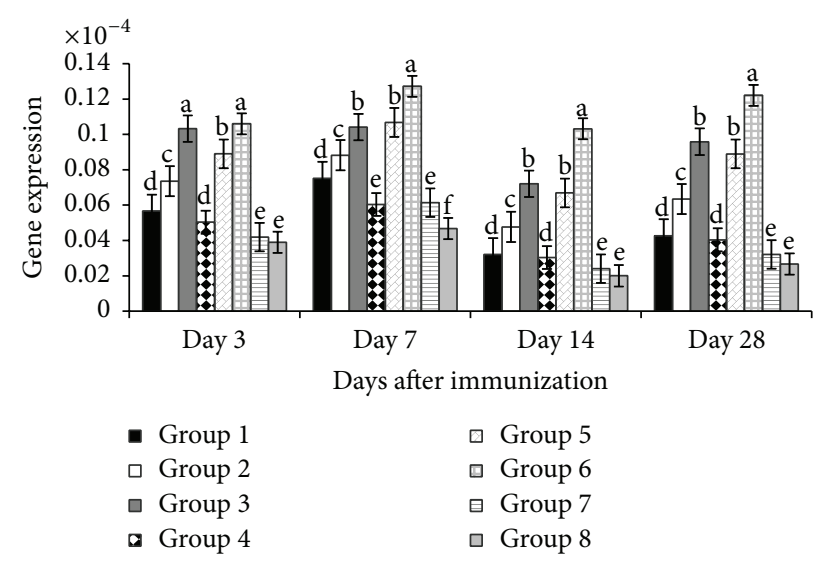

FIGURE 6: Effect of APS and GPS on gene expression of IL-10. Superscripts with different letters $(\mathrm{a}-\mathrm{f})$ differ significantly $(P<$ $0.05)$. Group $1=100 \mathrm{mg} / \mathrm{kg}$ APS + vaccine. Group $2=200 \mathrm{mg} / \mathrm{kg}$ APS + vaccine. Group $3=400 \mathrm{mg} / \mathrm{kg}$ APS + vaccine. Group $4=100 \mathrm{mg} / \mathrm{kg}$ GPS + vaccine. Group $5=200 \mathrm{mg} / \mathrm{kg}$ GPS + vaccine. Group $6=$ $400 \mathrm{mg} / \mathrm{kg}$ GPS + vaccine. Group 7 = vaccine only. Group $8=$ no vaccine, no GPS (blank control).

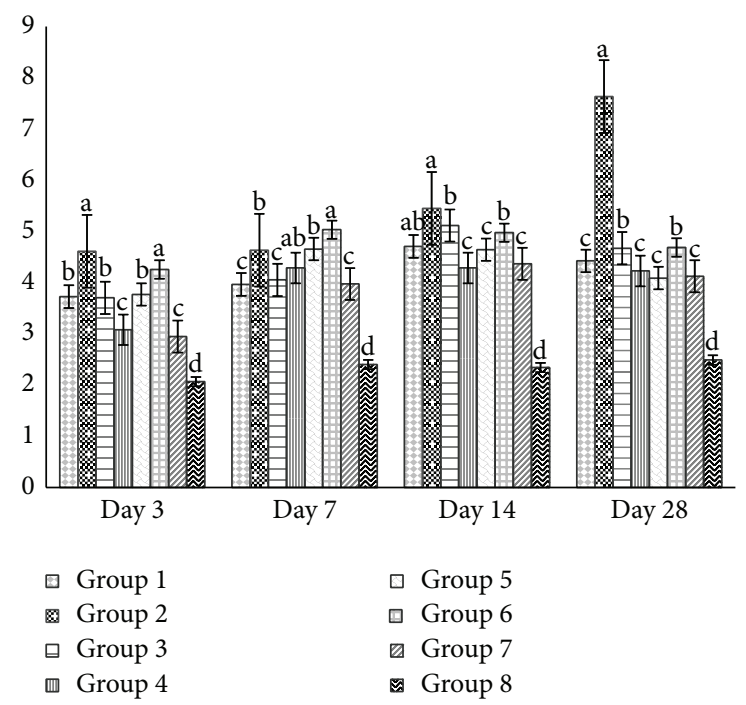

FIgURE 7: Effect of APS and GPS on IL-2 by ELISA. Superscripts with different letters $(\mathrm{a}-\mathrm{d})$ differ significantly $(P<0.05)$. Group 1 $=100 \mathrm{mg} / \mathrm{kg}$ APS + vaccine. Group $2=200 \mathrm{mg} / \mathrm{kg}$ APS + vaccine. Group $3=400 \mathrm{mg} / \mathrm{kg}$ APS + vaccine. Group $4=100 \mathrm{mg} / \mathrm{kg}$ GPS + vaccine. Group $5=200 \mathrm{mg} / \mathrm{kg}$ GPS + vaccine. Group $6=400 \mathrm{mg} / \mathrm{kg}$ GPS + vaccine. Group 7 = vaccine only. Group $8=$ no vaccine, no GPS (blank control).

$(P<0.05)$ than corresponding $200 \mathrm{mg} / \mathrm{kg}$ and $400 \mathrm{mg} / \mathrm{kg}$ APS treated groups.

3.4. Interleukins (IL-2 and IL-10) in Chicken's Serum by ELISA. Figures 7 and 8 revealed ELISA results for IL-2 and IL-10 and very high levels were produced after $\mathrm{H} 5 \mathrm{~N} 1$ vaccination. On days $3,7,14$, and 28 both IL-2 and IL-10 of APS at $200 \mathrm{mg} / \mathrm{kg}$ and $400 \mathrm{mg} / \mathrm{kg}$ of GPS groups were higher $(P<0.01)$ than vaccine group and blank control.

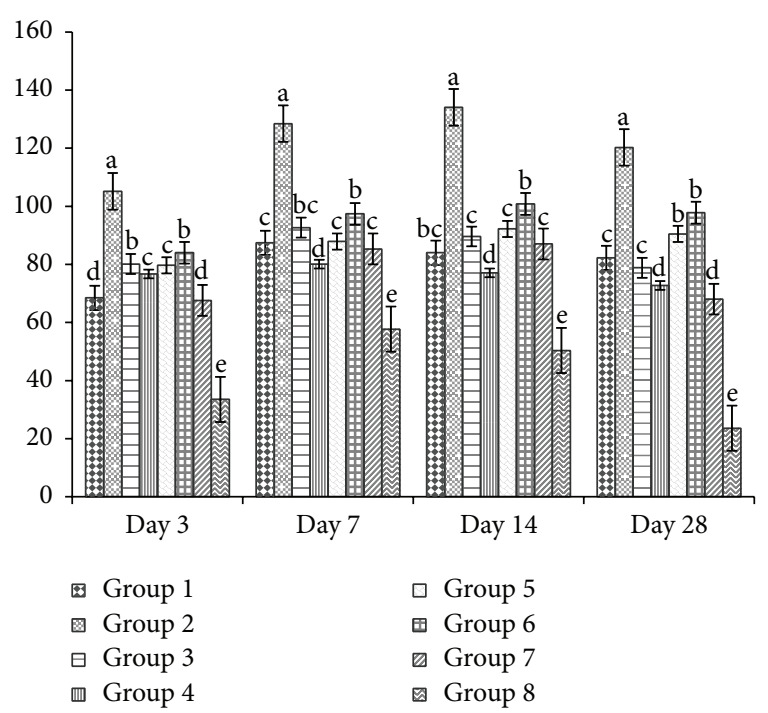

FIGURE 8: Effect of APS and GPS on IL-10 by ELISA. Superscripts with different letters $(\mathrm{a}-\mathrm{e})$ differ significantly $(P<0.05)$. Group 1 $=100 \mathrm{mg} / \mathrm{kg}$ APS + vaccine. Group $2=200 \mathrm{mg} / \mathrm{kg}$ APS + vaccine. Group $3=400 \mathrm{mg} / \mathrm{kg}$ APS + vaccine. Group $4=100 \mathrm{mg} / \mathrm{kg}$ GPS + vaccine. Group $5=200 \mathrm{mg} / \mathrm{kg}$ GPS + vaccine. Group $6=400 \mathrm{mg} / \mathrm{kg}$ GPS + vaccine. Group $7=$ vaccine only. Group $8=$ no vaccine, no GPS (blank control).

\section{Discussion}

The present study demonstrated that the combination of APS or GPS with $\mathrm{H} 5 \mathrm{~N} 1$ vaccine may have better protective effects against lethal H5N1 influenza virus infection in chickens. It was previously reported that APS and other Chinese herbs had adjuvant effect when coadministered with an influenza vaccine, and it increased both the innate and systemic humoral responses that provide complex protection against $\mathrm{H} 5 \mathrm{~N} 1$ in chickens [20]. In this study dynamic changes in body weight were observed on day 28 in which the experimental groups ( $400 \mathrm{mg} / \mathrm{kg}$ APS and GPS) were higher than vaccine group and blank control, probably due to better health situation of chickens (Table 2). The results further revealed that administration of GPS and APS was able to protect the chickens from viral damage after vaccination. This is in parallel with $\mathrm{Hu}$ [21] who reported that animals treated with Chinese herbal medicine or Chinese herbal ingredients before or after vaccination showed a reduced incidence of infectious diseases and an increased immune response. However, no significant difference in body weight gain was observed on day 3 in both GPS and APS treated groups (Table 2).

Serum HI Ab titer is a valid indicator of the humoral immunity in chickens [22]. Previous studies have shown that the $\mathrm{HI} \mathrm{Ab}$ is directly effective against NDV in chickens [23, 24]. Our result showed that the HI Ab titers in the treatment groups of GPS and APS were significantly higher than vaccine group after immunization (Figures 1 and 2), suggesting that GPS and APS could enhance the humoral immunity. It demonstrated that, on days 14 and 28 after vaccination, the anti-H5N1 HI Ab titers of the APS treated groups $(200 \mathrm{mg} / \mathrm{kg}$ and $400 \mathrm{mg} / \mathrm{kg}$ ) and $100 \mathrm{mg} / \mathrm{kg}, 200 \mathrm{mg} / \mathrm{kg}$, and $400 \mathrm{mg} / \mathrm{kg}$ GPS treated groups were higher than vaccine group and blank 
control, indicating a more rapid response and potent effects in increasing the production of anti-H5N1 antibodies of the GPS and APS treatment groups. These findings provide evidence for the use of GPS and APS as effective herbal medicinal immune stimulators.

More interestingly, vaccination of $\mathrm{H} 5 \mathrm{~N} 1$ caused decrease in body weight as shown in the results, but addition of both GPS and APS was able to recover the decreased body weights, probably due to body regulation to vaccination stress. The effects of APS and GPS on body weight gain were different, especially the doses from $200 \mathrm{mg} / \mathrm{kg}$ to $400 \mathrm{mg} / \mathrm{kg}$; it is fascinating that body weight gain was always lower using GPS rather than APS, probably due to their chemical components, although both contain polysaccharides as their constituents but the latter contains more simple sugars than the former, which might contribute to the effects. Refer to Ríos and Waterman [25] for detailed review on astragalus.

The reactivity of chicken spleen to antigens is higher in magnitude with increase in age [26]. The spleen constitutively expressed IL-4, IL-10, and IFN- $\gamma$ cytokine genes as early as embryonic day 12 which is associated with shaping the spleen environment. The expression patterns of these cytokines coincide with the completion of colonization of the spleen by cellular migrants from the thymus [26]. In this study we recorded that on days 7,14 , and 28 the TNF- $\alpha$ gene expression in the spleen of the APS and GSP $(200 \mathrm{mg} / \mathrm{kg}$ and $400 \mathrm{mg} / \mathrm{kg})$ treated groups was higher than corresponding vaccine group and blank control. TNF involves in a network of cytokines and chemokines that stimulates the recruitment of immune cells in the infectious foci and can block the viral replication by interfering with the viral life cycle especially in viral entry [27].

Previous reports found APS and GPS to promote IL-2 bioactivity [28]. Accordingly, the increased bioactivity of IL2 of peripheral blood lymphocytes may partly explain the increased lymphocytes proliferation. The Th2 cells secrete cytokines such as IL- 4 and IL-10 which help B cell proliferation and are associated with humoral immunity [28]. In our finding it was revealed that gene expressions of IL-2 and IL10 in APS and GPS groups were evidently higher than vaccine group and control, meaning that APS and GPS most probably stimulate cytokine production. Cytokines often have multiple effects, which originated from various effector cells. The variation of cytokines in our study coincided with finding of Shao et al. [29]. In comparison there was no significant difference in body weight; however, the cytokine gene expressions in the GPS groups were significant compared with corresponding APS groups. Hence APS which had been known over the centuries for its immune potency can be substituted by a more immune potent GPS as adjuvant in the formulation of a $\mathrm{H} 5 \mathrm{~N} 1$ vaccine. Our results indicated that oral supplement of both GPS and APS will be beneficial to health and vaccination efficiency in $\mathrm{H} 5 \mathrm{~N} 1$ vaccine in chickens. More interestingly, GPS exerted similar and even better improvement in this respect.

\section{Conclusion}

Conclusively our results showed the following. (1) The addition of APS and GPS is beneficial to eliminate the chicken weight loss after vaccination. (2) APS and GPS have adjuvant properties to enhance the antibody level when used in combination with influenza vaccine (H5N1). (3) Expressions of IL-2, IL-10, and TNF- $\alpha$ and IFN- $\beta$ in GPS and APS treated groups were higher than control group, suggesting GPS and APS stimulated cytokine production and macrophage activation. Intriguingly, expressions of IL- 2 and IL-10 by ELISA have proved similar results. (4) The effects of GPS and APS on growth rate and immune response were related to their dosages used. Appropriate effective dosages such as $200 \mathrm{mg} / \mathrm{kg}$ and $400 \mathrm{mg} / \mathrm{kg}$ should be taken into consideration in the use of GPS and APS as adjuvant in the formulation of a new $\mathrm{H} 5 \mathrm{~N} 1$ vaccine. (5) The study further revealed that the combination of APS or GPS with $\mathrm{H} 5 \mathrm{~N} 1$ vaccine may have better protective effects against lethal $\mathrm{H} 5 \mathrm{~N} 1$ influenza virus infection in chickens.

Generally, oral supplementation of GPS and APS dosages $(100 \mathrm{mg} / \mathrm{kg}, 200 \mathrm{mg} / \mathrm{kg}$, and $400 \mathrm{mg} / \mathrm{kg}$ ) was beneficial to the health of the chickens to eliminate the chicken weight loss after vaccination. Similarly doses of $200 \mathrm{mg} / \mathrm{kg}$ and $400 \mathrm{mg} / \mathrm{kg}$ GPS and APS in vivo would be expected to serve as adjuvant for new vaccine formulation against H5N1 AIV.

\section{Competing Interests}

The authors declare that they have no competing interests.

\section{Authors' Contributions}

Auwalu Yusuf Abdullahi and Sanpha Kallon contributed equally to this paper.

\section{Acknowledgments}

This work was supported by South China Agricultural University work team project (no. 2011A020102009) and China Postdoctoral Research Fund (2015M582391) and National Natural Science Foundation of China (Grant no. 31272551).

\section{References}

[1] World Health Organization Global Influenza Program Surveillance Network, "Evolution of H5N1 avian influenza viruses in Asia," Emerging Infectious Diseases, vol. 11, no. 10, pp. 1515-1521, 2005.

[2] World Health Organization, "H5N1 avian influenza: timeline," 2005, http://www.who.int/influenza/human_animal_interface/ avian_influenza/H5N1_avian_influenza_update.pdf.

[3] D. L. Suarez and S. Schultz-Cherry, "Immunology of avian influenza virus: a review," Developmental and Comparative Immunology, vol. 24, no. 2-3, pp. 269-283, 2000.

[4] D. J. Alexander and I. H. Brown, "Recent zoonoses caused by influenza A viruses," Revue Scientifique et Technique, vol. 19, no. 1, pp. 197-225, 2000.

[5] Y. Chen, D. Wang, Y. Hu et al., "Astragalus polysaccharide and oxymatrine can synergistically improve the immune efficacy of Newcastle disease vaccine in chicken," International Journal of Biological Macromolecules, vol. 46, no. 4, pp. 425-428, 2010. 
[6] J. Li, Y. Zhong, H. Li et al., "Enhancement of Astragalus polysaccharide on the immune responses in pigs inoculated with foot-and-mouth disease virus vaccine," International Journal of Biological Macromolecules, vol. 49, no. 3, pp. 362-368, 2011.

[7] D.-Q. Dou, Y.-W. Zhang, L. Zhang, Y.-J. Chen, and X.-S. Yao, "The inhibitory effects of ginsenosides on protein tyrosine kinase activated by hypoxia/reoxygenation in cultured human umbilical vein endothelial cells," Planta Medica, vol. 67, no. 1, pp. 19-23, 2001.

[8] Y.-W. Zhang, D.-Q. Dou, L. Zhang, Y.-J. Chen, and X.-S. Yao, "Effects of ginsenosides from Panax ginseng on cell-to-cell communication function mediated by gap junctions," Planta Medica, vol. 67, no. 5, pp. 417-422, 2001.

[9] K.-H. Kim, Y.-S. Lee, I.-S. Jung et al., "Acidic polysaccharide from Panax ginseng, ginsan, induces Th1 cell and macrophage cytokines and generates LAK cells in synergy with rIL-2," Planta Medica, vol. 64, no. 2, pp. 110-115, 1998.

[10] C.-S. Yuan, C.-Z. Wang, S. M. Wicks, and L.-W. Qi, "Chemical and pharmacological studies of saponins with a focus on American ginseng," Journal of Ginseng Research, vol. 34, no. 3, pp. 160-167, 2010.

[11] Y. Han, S.-J. Son, M. Akhalaia et al., "Modulation of radiationinduced disturbances of antioxidant defense systems by ginsan," Evidence-Based Complementary and Alternative Medicine, vol. 2, no. 4, pp. 529-536, 2005.

[12] S.-K. Han, J.-Y. Song, Y.-S. Yun, and S.-Y. Yi, "Ginsan improved Th1 immune response inhibited by gamma radiation," Archives of Pharmacal Research, vol. 28, no. 3, pp. 343-350, 2005.

[13] J.-Y. Ahn, I.-S. Choi, J.-Y. Shim et al., “The immunomodulator ginsan induces resistance to experimental sepsis by inhibiting Toll-like receptor-mediated inflammatory signals," European Journal of Immunology, vol. 36, no. 1, pp. 37-45, 2006.

[14] J.-Y. Ahn, J.-Y. Song, Y.-S. Yun, G. Jeong, and I.-S. Choi, "Protection of Staphylococcus aureus-infected septic mice by suppression of early acute inflammation and enhanced antimicrobial activity by ginsan," FEMS Immunology and Medical Microbiology, vol. 46, no. 2, pp. 187-197, 2006.

[15] S. Kallon, X. Li, J. Ji et al., "Astragalus polysaccharide enhances immunity and inhibits H9N2 avian influenza virus in vitro and in vivo," Journal of Animal Science and Biotechnology, vol. 4, no. 1, article 22, 2013.

[16] S. Kallon and A. Y. Abdullahi, "Immunity against avian influenza virus panax ginseng polysaccharide (GPS) can improve immunity against H9N2 avian influenza virus in chickens," Iranian Journal of Applied Animal Science, vol. 5, no. 3, pp. 715-722, 2015.

[17] W. J. Zhang, Biochemistry Technology of Polysaccharide Compound, Zhejiang University Press, Hangzhou, China, 1999.

[18] Y. F. Zhao, Theory and Application of Biochemistry Technology, Wuhan University Press, Wuhan, China, 1994.

[19] D. E. Swayne, D. A. Senne, and C. W. Beard, "Avian influenza," in A Laboratory Manual for the Isolation and Identification of Avian Pathogens, D. E. Swayne, Ed., pp. 150-155, Association of Avian Pathologists, Kennett Square, Pa, USA, 1998.

[20] Z. I. Rajput, C.-W. Xiao, S.-H. Hu, A. G. Arijo, and N. M. Soomro, "Improvement of the efficacy of influenza vaccination (H5N1) in chicken by using extract of Cochinchina momordica seed (ECMS)," Journal of Zhejiang University Science B, vol. 8, no. 5, pp. 331-337, 2007.

[21] Y. L. Hu, "Progress in the study of immunlpharmacology of Chinese herbal medicine," Chinese Journal of Immunology, vol. 3, pp. 96-98, 1997.
[22] X. F. Kong, Y. L. Hu, Y. L. Yin et al., "Chinese herbal ingredients are effective immune stimulators for chickens infected with the Newcastle disease virus," Journal of the American Association of Instructors and Investigators in Poultry Husbandry, vol. 85, no. 12, pp. 2169-2175, 2006.

[23] M. M. A. Mtambo, E. J. Mushi, L. D. B. Kinabo et al., "Evaluation of the efficacy of the crude extracts of Capsicum frutescens, Citrus limon and Opuntia vulgaris against Newcastle disease in domestic fowl in Tanzania," Journal of Ethnopharmacology, vol. 68, no. 1-3, pp. 55-61, 1999.

[24] R. A. Maas, M. Komen, M. van Diepen, H. L. Oei, and I. J. T. M. Claassen, "Correlation of haemagglutinin-neuraminidase and fusion protein content with protective antibody response after immunisation with inactivated Newcastle disease vaccines," Vaccine, vol. 21, no. 23, pp. 3137-3142, 2003.

[25] J. L. Ríos and P. G. Waterman, "A review of the pharmacology and toxicology of Astragalus," Phytotherapy Research, vol. 11, no. 6, pp. 411-418, 1997.

[26] C. Siatskas and R. Boyd, "Regulation of chicken haemopoiesis by cytokines," Developmental and Comparative Immunology, vol. 24, no. 1, pp. 37-59, 2000.

[27] G. Herbein and W. A. O’Brien, “Tumor necrosis factor (TNF)$\alpha$ and TNF receptors in viral pathogenesis," Proceedings of the Society for Experimental Biology and Medicine, vol. 223, no. 3, pp. 241-257, 2000.

[28] X. Y. Tang, G. B. Tian, C. S. Zhao, J. F. Zhou, and K. Z. $\mathrm{Yu}$, "Isolation and characterization of prevalent strains of avian influenza viruses in China," Chinese Journal of Preventive Veterinary Medicine, vol. 1, pp. 1-5, 1998.

[29] B.-M. Shao, W. Xu, H. Dai, P. Tu, Z. Li, and X.-M. Gao, "A study on the immune receptors for polysaccharides from the roots of Astragalus membranaceus, a Chinese medicinal herb," Biochemical and Biophysical Research Communications, vol. 320, no. 4, pp. 1103-1111, 2004. 

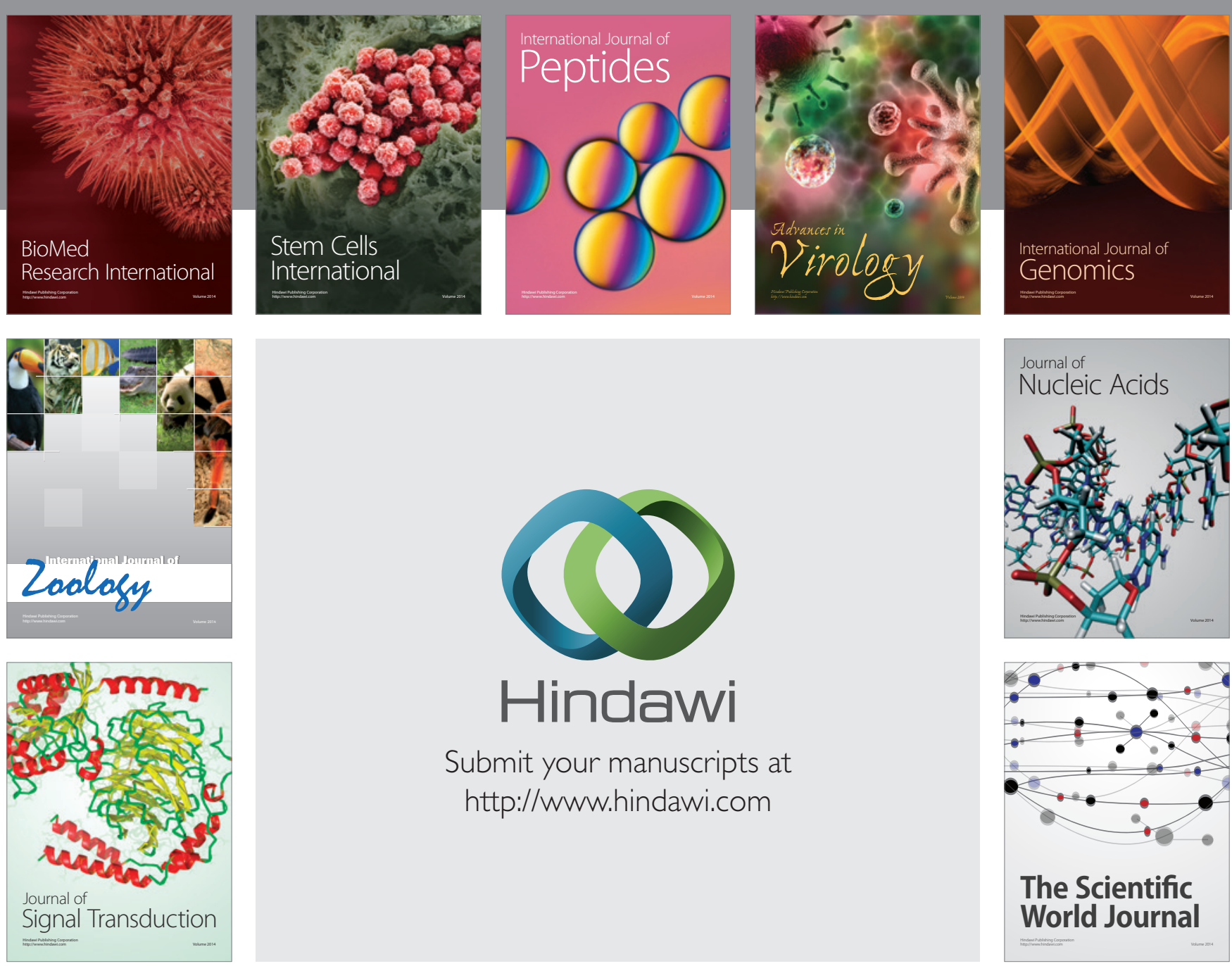

Submit your manuscripts at

http://www.hindawi.com
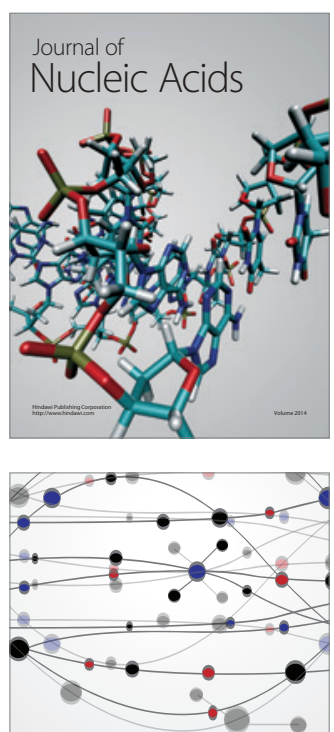

The Scientific World Journal
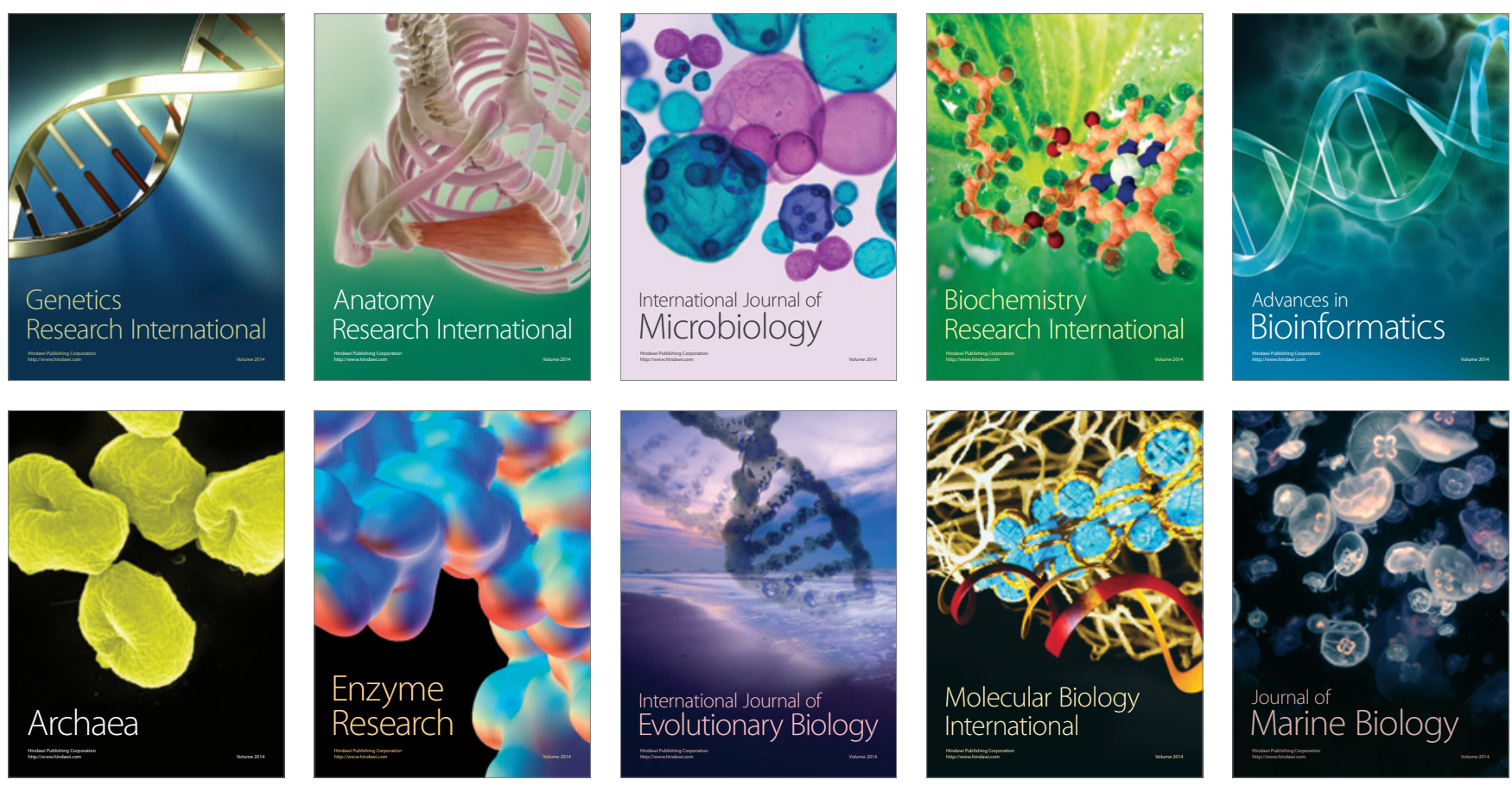